\title{
ANALISIS PENDAPATAN USAHA PENGGEMUKAN BABI BALI YANG MENGGUNAKAN PAKAN KOMERSIAL (STUDI KASUS DI DESA GEROKGAK-BULELENG)
}

\author{
SUKANATA, I W., B. R. T. PUTRI, SUCIANI, DAN I G. SURANJAYA \\ Fakultas Peternakan Universitas Udayana \\ e-mail: nata_suka@yahoo.com
}

\begin{abstract}
ABSTRAK
Penelitian ini dilaksanakan di Desa Gerokgak, Kecamatan Gerokgak, Kabupaten Buleleng dari bulan Agustus hingga Oktober 2016. Tujuannya adalah untuk menganalisis seberapa besar pendapatan yang diperoleh peternak dari usaha penggemukan babi bali yang menggunakan pakan komersial. Sebanyak 60 ekor anak babi bali dengan rata-rata umur 2 bulan digemukkan selama 1 bulan dengan menggunakan pakan komersial yang terdiri atas pollar dan pakan pabrikan CP 551 dengan perbandingan 2:1. Hasil penelitian ini menunjukkan bahwa rata-rata jumlah pakan yang dikonsumsi adalah $0,66 \mathrm{~kg} / \mathrm{ekor} /$ hari. Usaha penggemukan babi bali dengan skala ini membutuhkan biaya investasi pembangunan kandang dan peralatan sekitar 12 juta rupiah. Sedangkan biaya tetap dan biaya varibel yang diperlukan dalam satu periode produksi sebesar Rp. 33.866.667,-- Usaha ini mampu memberikan pendapatan kepada peternak sebesar Rp. 5.133.333 (65.556/ekor) dengan R/C 1,15. Usaha ini mencapai titik impas (break even point) pada jumlah pemeliharaan sebanyak 7 ekor, atau ketika harga babi Rp. 564.444/ekor.
\end{abstract}

Kata kunci: babi bali, penggemukan, analisis pendapatan

\section{INCOME ANALYSIS OF BALI PIG FATTENING USING COMERCIAL FEED (CASE STUDY IN GEROKGAK VILLAGE-BULELENG)}

\begin{abstract}
This study conducted in Gerokgak Village, Buleleng Regency from August to October 2016. It aims at analyzing farmer's income derived from bali pig fattening offered commercial feed. 60 piglets with an average age of 2 month fattened for 1 months by using comercial feed consists of pollard (wheat bran) and CP 551 with proportion 2:1. The results showed that the average of feed consumption was about $0,66 /$ head/day. This business cost 12 million to build the pen and property. Meanwhile, the fixed cost and variable cost required for this business cost Rp. 33.866.667. Bali pig fattened given contribution to farmer income at the amount of Rp.5.133.333 (85.556/head) with R/C of 1.15. Breakeven point can be reached when the number of pig fattenned of 7 pigs or Rp. 564.444 per pigs of selling price.
\end{abstract}

Keywords: bali pig, fattening, income analysis

\section{PENDAHULUAN}

Babi mempunyai peranan yang sangat penting bagi masyarakat Bali, baik dari sisi ekonomi maupun sosial budaya. Dari sisi ekonomi, ternak babi merupakan mesin biologis yang dapat menghasilkan daging, di samping juga sebagai sumber pendapatan bagi masyarakat. Ternak babi juga memberikan multiplier effect yang besar, karena mempunyai keterkaitan yang besar baik dengan industri di hulu dan di hilirnya. Dari sisi sosial budaya, ternak babi merupakan salah satu sarana upacara agama dan adat yang tidak tergantikan.

Salah satu jenis babi yang banyak dipelihara di
Bali adalah babi bali yang merupakan sumber plasma nutfah asli Bali. Saat ini populasinya di Bali sekitar 30\% dari populasi babi keseluruhan. Babi tersebut memiliki berbagai keunggulan dibandingkan babi ras, seperti lebih tahan terhadap lingkungan/cuaca yang ekstrim, dapat tumbuh dengan baik walaupun pakan yang diberikan seadanya, serta hemat air. Keunggulan tersebut membuat babi jenis ini menjadi pilihan petani di daerah-daerah marginal, seperti Kecamatan Kubu, Gerokgak, Nusa Penida, dan yang lainnya, karena di daerah itu ia masih mampu berproduksi dengan baik. Disamping itu, daging babi bali memiliki citarasa yang lebih gurih, dan sangat cocok dipakai sebagai babi 
guling (Budaarsa, 2012; 2014). Di beberapa daerah, dalam membuat babi guling atau membuat sesaji masih fanatik harus menggunakan menggunakan babi bali (Sumardani dan Ardika, 2016).

Pemeliharaan babi bali secara umum dilakukan secara tradisional (sebagai tatakan banyu) dengan pakan seadanya, yaitu berupa limbah dapur dan hasil sampingan di kebun/tegal. Cara pemeliharaan seperti memiliki banyak kekurangan baik dari sisi kuantitas maupun kualitas sehingga jumlah babi yang bisa dipelihara sangat terbatas. Akibatnya populasi babi bali tidak berkembang, bahkan cenderung turun rata-rata 2,92\% per tahun dari tahun 2009 sampai 2013.

Salah satu alternatif yang bisa dilakukan untuk mengatasi masalah ketersediaan pakan secara tradisional tersebut di atas adalah dengan menggunakan pakan komersial. Pakan komersial seperti konsentrat, pakan jadi, jagung giling, dedak padi, dan polar ketersediaannya berlimpah dan mudah diperoleh. Namun demikian, dalam memperolehnya dibutuhkan biaya yang cukup besar sehingga akan meningkatkan biaya produksi. Salah satu syarat bagi suatu komoditas peternakan agar dapat terus berkembang adalah mampu memberikan keuntungan bagi yang membudidayakannya. Berdasarkan hal tersebut, yang menjadi pertanyaan adalah, apakah dengan menggunakan pakan komersial usaha penggemukan babi bali menguntungkan atau tidak secara finansial, dan jika menguntungkan sejauh mana tingkat keuntungan yang diberikan? Dengan demikian maka kajian ini sangat penting dilakukan untuk menjawab pertanyaan-pertanyaan tersebut.

\section{MATERI DAN METODE}

\section{Lokasi dan Waktu Penelitian}

Penelitian ini dilaksanakan di Desa Gerokgak, Kecamatan Gerokgak, Kabupaten Buleleng. Lama penelitian selama 2 bulan yaitu dari bulan Agustus sampai Oktober 2015.

\section{Ternak dan Pakan}

Ternak yang digunakan dalam penelitian ini adalah babi bali lepas sapih umur 2 bulan. Jumlah ternak yang digunakan sebanyak 60 ekor, dipelihara dalam kandang selama 1 bulan. Kandang yang digunakan adalah kandang koloni sebanyak 6 unit, dengan ukuran masing-masing yaitu panjang 2,5 $\mathrm{m}$, lebar 2,5 $\mathrm{m}$ dan tinggi $1 \mathrm{~m}$. Setiap unit kandang dilengkapi dengan tempat makan dan air minum. Ransum yang digunakan adalah perpaduan dari pollar dengan pakan komersial merk CP 551 dengan komposisi $2: 1$.

\section{Data yang Digunakan}

Data utama yang digunakan dalam penelitian ini merupakan data sekunder yang bersumber dari pembukuan usaha milik Bapak Drs. Nyoman Atmajaya yang ada di Desa Gerokgak, Kecamatan Gerokgak, Kabupaten Buleleng. Pengamatan langsung juga dilakukan untuk melihat aktivitas di peternakan ini.

\section{Analisa Statistik}

Data dianalisis untuk menentukan pendapatan bersih (net farm income), revenue cost ratio ( $\mathrm{R} / \mathrm{C}$ ratio), titik impas harga, dan titik impas produksi.

Pendapatan bersih merupakan selisih antara penerimaan dengan semua biaya yang dikeluarkan, yang ditentukan dengan rumus (Soekartawi, 2002):

$$
\begin{aligned}
& \mathrm{Pd}=\mathrm{TR}-\mathrm{TC} \\
& \text { Keterangan: } \\
& \mathrm{Pd}=\text { pendapatan bersih } \\
& \mathrm{TR}=\text { penerimaan } \\
& \mathrm{TC}=\text { total biaya }
\end{aligned}
$$

Biaya diklasifikasikan menjadi biaya tetap (fixed cost) dan biaya tidak tetap (variable cost). Biaya investasi seperti biaya bangunan kandang dan peralatan diperhitungkan sebagai biaya penyusutan dengan menggunakan metode garis lurus (Ibrahim 2003).

$\mathrm{R} / \mathrm{C}$ ratio ditentukan dengan membagi total penerimaan (TR) dengan total biaya (TC) seperti rumus berikut (Soeharjo dan Patong, 1973).

$$
\mathrm{R} / \mathrm{C}=\frac{\mathrm{TR}}{\mathrm{TC}}
$$

Nilai R/C ratio yang lebih besar dari satu berarti menguntungkan, dan sebaliknya jika nilainya kurang dari satu. Jika R/C ratio sama dengan satu, berarti usaha tersebut berada dalam keadaan impas.

Titik impas produksi dan titik impas harga ditentukan dengan rumus berikut (Ibrahim, 2003):

$$
\mathrm{Q}_{\mathrm{BEP}}=\frac{\mathrm{TFC}}{\left(\mathrm{P}_{\mathrm{Q}}-\mathrm{PC}\right)} \quad \mathrm{P}_{\mathrm{BEP}}=\frac{\mathrm{TFC}+\mathrm{TVC}}{\mathrm{Q}}
$$

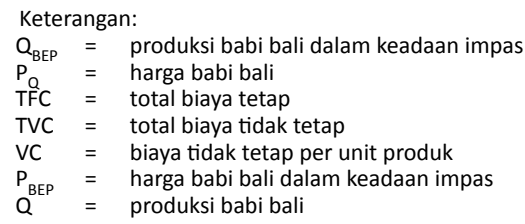

\section{HASIL DAN PEMBAHASAN}

\section{Biaya Usaha}

Biaya usaha merupakan semua pengeluaran dari suatu usaha untuk menghasilkan output (Kadarsan, 1995). Besarnya biaya yang diperlukan oleh suatu perusahaan sangat tergantung dari besarnya skala 
usaha tersebut. Menurut Ibrahim (2003), biaya usaha dapat dibedakan menjadi biaya investasi dan biaya modal kerja. Biaya modal kerja tersebut juga dapat digolongkan menjadi biaya tetap ( fixed cost) dan biaya tidak tetap (variable cost).

Usaha penggemukan babi bali dengan skala pemeliharaan sebanyak 60 ekor memerlukan dana investasi untuk membangun kandang dan peralatan sebesar Rp. 12.000.000. Sedangkan besarnya modal kerja atau biaya operasional yang dibutuhkan untuk menggemukkan 60 ekor babi bali dalam satu periode produksi (selama 1 bulan) adalah sebesar Rp. 33.866.667. Biaya tersebut meliputi biaya tidak tetap (variable cost) dan biaya tetap (fixed cost) yang terdiri atas beberapa komponen biaya seperti yang dapat dilihat pada Tabel 1 .

Tabel 1. Pendapatan dan biaya dari usaha penggemukan babi bali dengan skala 60 ekor dalam satu periode produksi (1 bulan)

\begin{tabular}{|c|c|c|c|c|c|c|}
\hline No & Uraian & Jumlah & Satuan & $\begin{array}{l}\text { Harga } \\
\text { Per } \\
\text { satuan }\end{array}$ & $\mathrm{Rp}$ & $\%$ dari TC \\
\hline \multirow[t]{2}{*}{1} & Penerimaan & & & & & \\
\hline & $\begin{array}{l}\text { Penjualan babi muda } \\
\text { (umur } 3 \text { bulan) }\end{array}$ & 60 & ekor & 650.000 & 39.000 .000 & 115,16 \\
\hline \multirow[t]{8}{*}{2} & Biaya Variabel & & & & & \\
\hline & Bibit (umur 2 bulan) & 60 & ekor & 400.000 & 24.000 .000 & 70,87 \\
\hline & Biaya Pakan & & & & & \\
\hline & Polar & 800 & $\mathrm{~kg}$ & 5.500 & 4.400 .000 & 12,99 \\
\hline & CP 551 & 400 & $\mathrm{~kg}$ & 8.000 & 3.200 .000 & 9,45 \\
\hline & $\begin{array}{l}\text { Obat-obatan } \\
\text { (insidentil) }\end{array}$ & 60 & paket & 25.000 & 1.500 .000 & 4,43 \\
\hline & Listrik dan air & 1 & paket & 100.000 & 100.000 & 0,30 \\
\hline & $\begin{array}{l}\text { Jumlah Biaya } \\
\text { Variabel }\end{array}$ & & & & 33.200 .000 & 98,03 \\
\hline \multirow[t]{4}{*}{3} & Biaya Tetap & & & & & \\
\hline & $\begin{array}{l}\text { Penyusutan kandang } \\
\text { (Rp/periode) }\end{array}$ & 1 & periode & 66.667 & 66.667 & 0,20 \\
\hline & $\begin{array}{l}\text { Biaya Tenaga Kerja } \\
\text { (Rp/ekor/periode) }\end{array}$ & 1 & Orang & 600.000 & 600.000 & 1,77 \\
\hline & Jumlah Biaya Tetap & & & & 666.667 & 1,97 \\
\hline 4 & Total Biaya & & & & 33.866 .667 & 100,00 \\
\hline 5 & Pendapatan Bersih & & & & 5.133 .333 & 15,16 \\
\hline 6 & $\mathrm{R} / \mathrm{C}$ & & & & 1,15 & \\
\hline
\end{tabular}

Biaya pembelian bibit dan pakan pada kelompok biaya tidak tetap cukup besar yaitu mencapai $95,18 \%$ dari total biaya tidak tetap atau sekitar 93,31\% dari total biaya (TC). Biaya pakan kemungkinan akan masih bisa ditekan dengan memperbesar skala produksi. Dengan memperbesar skala produksi maka akan membutuhkan pakan yang lebih banyak. Pembelian pakan dalam jumlah yang lebih besar umumnya akan mendapat harga yang lebih murah dibandingkan dengan pembelian dalam jumlah sedikit. Sedangkan biaya bibit kemungkinan juga akan dapat ditekan dengan mengkombinasikan antara usaha penggemukan dengan usaha pembibitan. Namun demikian, perlu dikaji terlebih dahulu sejauhmana kelayakan finansial usaha pembibitan babi bali.

Komponen biaya tetap terdiri dari upah tenaga kerja, biaya air dan listrik, serta biaya penyusutan. Besarnya biaya yang diperlukan untuk upah tenaga kerja adalah sebesar Rp. 600.000 per periode ( 1 bulan).

\section{Pendapatan Usaha}

Besarnya penerimaan yang diperoleh dari usaha babi bali sebanyak 60 ekor selama 1 bulan adalah sebesar Rp. 39.000.000. Penerimaan ini diperoleh dari penjualan babi bali hidup dengan sistem cawangan (tanpa melalui timbangan) dengan harga 650.000,-/ ekor. Setelah dikurangi dengan semua biaya maka diperoleh pendapatan bersih (keuntungan) sebesar Rp. 5.133.333 atau rata-rata sekitar Rp. 85.556/ekor. Saat ini jumlah pemeliharaan babi penggemukan di Desa Gerokgak berkisar antara 1-6o ekor dengan rataan 3,58 ekor per peternak. Dengan demikian, peternakan babi dijadikan sebagai usaha sambilan. Hal ini didukung oleh Sumadi et al. (2016) yang menyatakan bahwa ternak babi bali telah dipelihara oleh petani sebagai "celengan" (tabungan). Pendapatan peternak tersebut masih berpotensi ditingkatkan dengan memperbaiki manajemen pemeliharaan dan meningkatkan efisiensi pemasaran.

Babi bali sangat diminati oleh pedagang babi guling untuk dijadikan babi guling. Hal ini sejalan dengan Miwada et al. (2014) yang menyatakan bahwa sekitar $37,20 \%$ dari jumlah warung makan babi guling di Bali menggunakan jenis babi bali sebagai bahan bakunya. Babi bali memang sangat cocok dijadikan sebagai babi guling seperti yang disampaikan oleh Budaarsa (2012; 2014) yang menyatakan bahwa babi bali memiliki citarasa yang lebih gurih, dan sangat cocok dipakai sebagai babi guling. Hal ini juga didukung oleh Suarna dan Suryani (2014) yang menyatakan bahwa babi bali sangat potensial sebagai babi guling karena komposisi lipatan lemak di bawah kulit akan memberikan aroma dan tekstur yang sangat baik. Namun demikian, karena keterbatasan populasi babi bali seringkali pedagang babi guling tidak mendapat pasokan babi bali secara kontinyu untuk dijadikan babi guling. Hal ini tentu menjadi peluang dan sekaligus tantangan bagi peternak babi bali untuk dapat memenuhi permintaan babi bali secara berkelanjutan.

\section{R/C Ratio}

Pendapatan yang besar tidak selalu menunjukkan efisiensi yang tinggi dalam pencapaiannya. $\mathrm{R} / \mathrm{C}$ ratio merupakan salah satu ukuran yang dapat digunakan untuk mengukur efisiensi pencapaian pendapatan. Semakin besar nilai $\mathrm{R} / \mathrm{C}$ ratio dari suatu usaha maka 
semakin efisien pencapaian pendapatan dari usaha tersebut. Usaha penggemukan babi bali selama 4 bulan menghasilkan R/C ratio sebesar 1,15. Angka ini menunjukkan bahwa dari setiap rupiah biaya yang dikeluarkan akan diperoleh penerimaan sebesar Rp. 1,15. Angka ini menunjukkan bahwa usaha penggemukkan babi bali cukup menguntungkan, dimana mampu memberikan keuntungan sekitar $15 \%$ dari biaya yang dikeluarkan per periode produksi (1 bulan). Angka ini tentu jauh lebih besar dari bunga bank. Namun demikian kalau dibandingkan dengan $\mathrm{R} / \mathrm{C}$ ratio dari usaha penggemukan babi ras angka ini jauh masih sangat jauh di bawahnya. Menurut Parwati et al. (2014), penggemukan babi peranakan landrace umur 8 minggu selama 114 hari mampu memberikan R/C berkisar 1,4-1,61.

\section{Titik Impas}

Usaha ini mencapai titik impas (break even) pada jumlah pemeliharaan sebanyak 7 ekor, atau ketika harga babi bali hidup Rp. 564.444/ekor. Artinya, ketika jumlah pemeliharaan sebanyak 7 ekor maka usaha penggemukan babi bali berada dalam kondisi tidak untung tetapi juga tidak rugi. Jika jumlah pemeliharaan di atas jumlah tersebut maka usaha ini akan untung, dan jika jumlah pemeliharaan kurang dari 7 ekor maka akan rugi. Begitu pula jika harga babi bali hidup lebih dari Rp 564.444,-/ekor maka usaha ini akan menguntungkan, dan sebaliknya akan merugikan jika harganya di bawah angka tersebut.

\section{SIMPULAN}

Usaha penggemukan babi bali dengan skala pemeliharaan 60 ekor menggunakan pakan komersial yaitu kombinasi antara CP 551 dengan polar mampu menghasilkan pendapatan bersih (keuntungan) sebesar Rp.5.133.333 (Rp. 85.556/ekor) per periode produksi (1 bulan) dengan $\mathrm{R} / \mathrm{C}$ 1,15. Usaha ini dapat mencapai titik impas (break even) pada jumlah pemeliharaan sebanyak 7 ekor, atau ketika harga penjualan babi muda Rp. 564.444/ekor.

\section{UCAPAN TERIMAKASIH}

Pada kesempatan ini penulis mengucapkan terimakasih yang sebesar-besarnya kepada Bapak Rektor, Ketua Lembaga Penelitian dan Pengabdian Masyarakat, dan Dekan Fakultas Peternakan Universitas Udayana atas kepercayaan dan kesempatan serta pendanaan yang diberikan untuk melakukan penelitian ini. Kami juga mengucapkan terimakasih kepada semua pihak yang telah membantu kegiatan ini sehingga dapat berjalan sesuai dengan harapan.

\section{DAFTAR PUSTAKA}

Budaarsa, K. 2012. Babi Guling Bali. Buku Arti. Denpasar Budaarsa, K. 2014. Potensi ternak babi dalam pemenuhan daging di Bali. Prosiding. Seminar dan Lokakarya Nasional Ternak Babi. Fakultas Peternakan, Universitas Udayana. Denpasar.

Budaarsa, K., A.W. Puger, dan I M. Suasta. 2016. Eksplorasi komposisi pakan tradisional babi bali. Majalah Ilmiah Peternakan. Vol. 19 No. 1. Tahun 2016. Hal. 6-11.

Dinas Peternakan dan Kesehatan Hewan Provinsi Bali. 2014. Informasi Data Peternakan Provinsi Bali Tahun 2013. Denpasar.

Ibrahim, H.M.Y. 2003. Studi Kelayakan Bisnis. Rineka Cipta., Jakarta.

Kadarsan, Halimah W. 1995. Keuangan Pertanian dan Pembiayaan Perusahaan Agribisnis. Gramedia Pustaka Utama, Jakarta.

Miwada, I N.S., I G. Mahendra, K. Budaarsa, dan Martini, H. 2014. Studi kebutuhan babi untuk warung makan babi guling di Bali. Prosiding. Seminar dan Lokakarya Nasional Ternak Babi. Fakultas Peternakan, Universitas Udayana. Denpasar.

Parwati, I. A., L. G. Budiari, dan N. Suyasa. 2014. Analisis usahatani penggemukan ternak babi dengan pengaturan ransum. Prosiding. Seminar dan Lokakarya Nasional Ternak Babi. Fakultas Peternakan Universitas Udayana. Denpasar.

Soekartawi. 2002. Analisis Usahatani. UI-Press. Jakarta.

Suarna, I W., dan N. N. Suryani. 2014. Peluang dan tantangan pengembangan ternak babi bali di kabupaten Gianyar Provinsi Bali. Prosiding. Seminar dan Lokakarya Nasional Ternak Babi. Fakultas Peternakan, Universitas Udayana. Denpasar.

Sumadi, I K., I M. Suasta, I P. A. Astawa, dan A. W. Puger. 2016. Pengaruh ME/CP ratio ransum terhadap performans babi bali. Majalah Ilmiah Peternakan. Vol. 19 No. 2. hal. 77-79.

Sumardani, N. L. G. dan I N. Ardika. 2016. Populasi dan perporma reproduksi babi bali betina di kabupaten Karangasem sebagai plasma nutfah asli Bali. Majalah Ilmiah Peternakan. Vol. 19 No. 3. hal. 105-109. 